\section{UCDNN}

LIBRARY
University of Connecticut OpenCommons@UConn

Faculty Articles and Papers

School of Law

1993

\title{
Ethics and Style: The Lessons of Literature for Law
}

Thomas Morawetz

University of Connecticut School of Law

Follow this and additional works at: https://opencommons.uconn.edu/law_papers

Part of the Legal Education Commons, and the Legal Ethics and Professional Responsibility Commons

\section{Recommended Citation}

Morawetz, Thomas, "Ethics and Style: The Lessons of Literature for Law" (1993). Faculty Articles and Papers. 223.

https://opencommons.uconn.edu/law_papers/223 


\section{HEINONLINE}

Citation: 45 Stan. L. Rev. 497 1992-1993

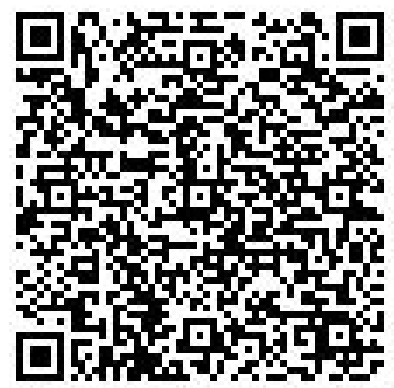

Content downloaded/printed from

HeinOnline (http://heinonline.org)

Mon Aug 15 17:11:19 2016

-- Your use of this HeinOnline PDF indicates your acceptance of HeinOnline's Terms and Conditions of the license agreement available at http://heinonline.org/HOL/License

-- The search text of this PDF is generated from uncorrected OCR text.

-- To obtain permission to use this article beyond the scope of your HeinOnline license, please use:

https://www.copyright.com/ccc/basicSearch.do?

\&operation $=$ go\&search Type $=0$

\&lastSearch $=$ simple\&all=on\&titleOrStdNo=0038-9765 


\title{
Ethics and Style: The Lessons of Literature for Law
}

\author{
Thomas Morawetz*
}

Poethics and OTHER STRATEgies of LAW AND Literature. By Richard Weisberg. New York: Columbia University Press. 1992. 312 pp. $\$ 32.95$.

\section{LAW AND LITERATURE IN A NUTSHELL}

"And" is a discreet copula. It says nothing about the relationship of the entities it joins. Consider Romeo and Juliet, but also Laurel and Hardy, as well as fish ' $n$ ' chips. The phrase "law and literature" is suggestive but unilluminating. A growing cohort of legal scholars claims to be practitioners of law and literature. 1 What activity keeps them off the streets and in the classroom?

Long-standing subjects within the law curriculum have two faces, one settled and one not. The settled face is the core of the subject: the introductory problems and principles that make up the basic course or textbook. Much less settled are the concerns of the scholar when she follows her muse in research. ${ }^{2}$ This distinction disappears in a field as seemingly inchoate as law and literature. What (and how) one teaches is every bit as indeterminate as what one writes.

Consider the possibilities.

First, "law and literature" can mean "law in literature," the study of depictions of lawyers and legal institutions in literature. This is the traditional understanding of the phrase and is reflected in the broadest expectation of students. ${ }^{3}$

On the other hand, "law and literature" can mean "law as literature,"

* Professor of Law, University of Connecticut School of Law. I wish to thank Marcella Hourihane for her help in preparing this essay.

1. Weisberg estimates that courses in law and literature are now offered at a majority of American law schools and that the 1980s saw a tenfold increase in books and articles in the field over the 1970s. P. ix.

2. This generalization requires more qualification than most. The settled face of a classroom subject is never impervious to change, even rapid change. Subjects that evolve quickly, such as constitutional law and criminal procedure, are hardly ever settled. Scholars may reconfigure the classroom agenda of even well-established subjects in law-contracts, torts, constitutional law-in the light of their intellectual commitments. Over the last 20 years, for example, law and economics has reshaped the agenda of torts.

3. Until ten years ago, "law and literature" designated this approach and consisted, more often than not, of a leisurely traversal of novels about lawyers. 
the investigation of literary techniques in legal texts. One may look at the rhetorical strategies of lawyers, at their use of logic, and at legal syntax and semantics. ${ }^{4}$ The once well-bounded subject of semantics has in recent decades become an omnivorous and Hydra-headed concern. The erstwhile preoccupation of linguists and occasional philosophers with how words mean has grown into the focal concern of postmodern thought. The primary question is whether meaning is found by individuals or is invented by communities. ${ }^{5}$ Practitioners of deconstruction raise deep and unsettling questions about all fields that depend on stable communication through texts and other utterances, implicating law as decisively as literature and philosophy. ${ }^{6}$

Calling a postmodern approach to legal texts "law as literature" seems altogether inadequate. Postmodern strategies permeate the law curriculum. Deconstruction is an essential strategy of such jurisprudential movements as critical legal studies and feminism, ${ }^{7}$ and questions about interpretation of

4. This approach until recently fell under the formal rubric of "legal reasoning" or was incorporated into courses on legal method. The reshaping of the prevailing conception of legal reasoning to embrace analogies with literature and philosophy seems to have gone through three recent stages. At first, legal reasoning was studied through brief but sophisticated handbooks of a pragmatic bent. For a widely read and influential example of this first stage, see EDWARD H. LEVI, AN INTRODUCTION TO LEGAL REASONING (1948). The 1970s were characterized by an eclectic and encyclopedic approach. See, e.g., William R. Bishin \& Christopher D. Stone, Law, LANGUAGE, ANd EthICs (1972). The third stage is distinguished by a sophisticated literary concern with legal rhetoric and reasoning. See, e.g., Stanley Fish, Is There A TEXT IN This Class?: The Authority of INTERPRETIVe COMMUNITIES (1980); RichaRd WeISBERg, WheN LAWYERS WrTte (1987); James Boyd White, Heracles' Bow: Essays on the Rhetoric and Poetics of the LaW (1985).

5. Postmodernism has as many definitions as it has devotees and/or critics. A particularly useful description is the following:

Sometime just after the middle of this century a revolution took place in philosophy-a "paradigm shift"-that represents so radical a change in conceptions of knowledge and language that inhabitants of the old and new philosophical worlds often talk past one another.... Heretofore, reference had been the key to meaning; from this point on, the key to meaning is use. Heretofore, the proposition, the assertion of a fact, had been seen as the paradigm for all language; from this point on, the multiple uses of language and its many complex relations to the world came to be appreciated. . . Moderns suppose that any individual (given the basic sensory and intellectual equipment) is as competent as any other to form justified beliefs and speak the language. Society's knowledge and language are merely the collection of the individuals'. In postmodern thought, on the other hand, the community plays an indispensable role... The language games and conventions in which one participates precede individual speech and determine what can and cannot be said. In short, language and the search for knowledge are communal achievements.

Nancey Murphy, Scientific Realism and Postmoderm Philosophy, 41 BRIT. J. PHIL. ScI. 291, 292, 294, 295 (1990).

6. For background on the nature and methods of deconstruction, see generally Harold Bloom, Paul de Man, Jacques Derrida, Geoffrey H. Hartman \& J. Hillis Miller, Deconstruction and Criticism (1979); Jonathan Culler, ON Deconstruction: Theory AND Criticism AFter Structuralism (1982); Christopher Norris, Deconstruction TheORY AND PRACTICE (rev. ed. 1991).

7. Critical theorists standardly define their task as "begin[ning] and proceed[ing] with the operation of law as ideology," INTROduction to CRITICAL Legal Studies 3 (Alian C. Hutchinson ed., 1989), or as "focus[ing] a more critical eye upon the theoretical assumptions embedded in modern legal theory." Katharine T. Bartlett \& Rosanne Kennedy, Introduction to FEMINIST LEGAL THEORY: READINGS IN LAW AND GENDER 2 (Katharine T. Bartlett \& Rosanne Kennedy eds., 1991). 
texts pervade constitutional law and theory. Law and literature in this sense of "law as literature" is continuous with much of the syllabus of legal theory.

A third way of approaching "law and literature" is by seeing it as the law of literature. Law and literature in this sense is part of the study of constitutional and statutory law. Law's concerns with literature include finding and determining the limits of free expression and the proper role for governments in the dissemination of art. It implicates questions at the heart of public debate: the feminist critique of obscenity law and pornography, ${ }^{8}$ the role of governmental programs funding the arts, ${ }^{9}$ and the policies and priorities of public broadcasting. ${ }^{10}$

Yet another way of pursuing "law and literature" is as a historian. One may examine the ways in which literature, in reflecting and shaping public opinion, has affected law. For example, one might examine the ways in which the insights of Charles Dickens, Emile Zola, or Upton Sinclair spurred individuals to demand legal reform and goaded legislators and courts to respond.

These four interdisciplinary paths to law draw respectively on literary analysis, philosophy, constitutional law, and legal history. It may appear, then, that the discipline of law and literature is actually the intersection of several distinct and barely overlapping concerns. Embarrassed by this state of affairs, a number of scholars seek to validate the field by identifying a significant core. ${ }^{11}$

\section{WeISBERG'S "PoEthicAL" Mission}

Richard Weisberg, who teaches law and literature at Cardozo School of Law, is deeply committed to defining and defending such a core. According to Weisberg, "[w] hat has so far been lacking-a void the present volume seeks to fill-is a guidebook to Law and Literature theory and practice.... . Part one [of this book] establishes the theoretical basis for an ambitious interdisciplinary enterprise."12 He then argues that:

Literature teaches about law in two discrete if related ways. First, by the how of literature-or how literature means ... - and second, by the what of literature-the rationalized rearticulation of its "lessons" for law. . . .

[W] hen a novel represents a legal process, or a lawyer in action, it "teaches"

8. Catharine A. MacKinnon, Feminism Unmodified: Discourses on Life and LaW 223-25 (1987).

9. See, e.g., Martin Tolchin, Congress Passes Bill Curbing Art Financing, N.Y. TIMEs, Oct. 8, 1989 , at L27.

10. See, e.g., Martin Tolchin, Public Broadcasting Wins Senate Battle for Federal Money, N.Y. TIMES, June 4, 1992, at A1.

11. Although Weisberg, as we shall see, is particularly devoted to this task, James Boyd White and Richard Posner are also deeply concerned about giving a clear and univocal focus to the inquiries of law and literature. Judge Posner, for example, describes his work as "the first to attempt a general survey and evaluation of the field of law and literature, [one that] seeks to organize, augment, and redirect ... scholarship in the field." Richard A. POSNER, LAW AND LITERATURE: A MisuNDERSTOOD RELATION, at x (1988).

12. Pp. ix-X. 
about law in both of these ways. ${ }^{13}$

Weisberg defends this thesis by examining exemplary literary works that depict law. He also considers legal texts and transactions that either illustrate or betray the lessons taught by such examples. He is mindful to uncover the 'mistakes' of other scholarly Galahads who have claimed to find the Holy Grail of law and literature, the well-secreted core of the discipline. In doing so he takes on Stanley Fish, Richard Posner, and James Boyd White.

These several analyses and arguments are collected in Weisberg's new book, Poethics and Other Strategies in Law and Literature. The three parts of the book concern, respectively, Weisberg's own position, fictional works about law and lawyers, and the rhetoric of law and lawyers.

Poethics has a uniquely odd internal structure ${ }^{14}$ which exemplifies a more general problem: its elusiveness and inaccessibility. While Weisberg applauds directness, he practices indirection. This may already appear evident from his summarial (and disturbingly elastic) statement about lessons to be drawn from the how and the what of literature. ${ }^{15}$ On the one hand, this statement is blandly uninformative, as it may say only that literature communicates through its content and its form. On the other hand, the statement may belie a significant thesis, namely that form and content are related in a special way or that the form and content of such literature have generally been misunderstood.

This review essay will show the difficulty of finding such a thesis in Poethics, a task that is logically prior to evaluating, criticizing, and drawing lessons from that thesis. Many of these difficulties have a common diagnosis which is best stated if I engage in a bit of indirection myself.

In his famous essay on Tolstoy, Isaiah Berlin distinguishes between hedgehogs and foxes. "There is a line among the fragments of the Greek poet Archilochus which says: 'The fox knows many things, but the hedgehog knows one big thing." "16 Berlin draws from this a profound and useful lesson: "[T]here exists a great chasm between those, on one side, who relate everything to a single central vision . . . and, on the other side, those who pursue many ends, often unrelated and even contradictory ...."17 The perplexities of Weisberg's book derive from a common source: $\mathrm{He}$ is a fox who thinks and claims he is a hedgehog.

Tracking Weisberg's fox-or-hedgehog footprints through his essays gives insight into both law and literature and Weisberg's views. Poethics provides an opportunity to explore the extent to which Weisberg's work in law and literature-or that of Fish, White, and Posner-lends itself to broad and significant generalizations. Contrary to Weisberg's assertions, it may be im-

13. P. 4.

14. See text accompanying note 115 infra.

15. See text accompanying note 13 supra.

16. Isaiah Berlin, The Hedgehog and the Fox: AN Essay on Tolstoy's View of HisTORY 1 (1953).

17. $I d$. 
possible to specify the significance of the copula in an interesting and univocal way.

In Poethics, Weisberg follows four major paths to the core of law and literature. First, he scrutinizes literature that portrays the work and character of lawyers. Weisberg mines these works of fiction as an iconoclast, challenging familiar ways of seeing their form and content. Second, Weisberg examines writings of lawyers themselves, memoranda and opinions that decisively reflect the presence or absence of a literary sensibility. Third, he criticizes other scholars. Weisberg is distressed by what he sees as trendy relativism of both value and meaning in the work of rival scholars. $\mathrm{He}$ is equally critical of claims that the traditional canon of literature is unrepresentative and reflects the assumptions of a dominant class, of Fish's speculations about interpretive communities, and of White's insights on law and literature as rhetoric. Finally, Weisberg examines style, or as he puts it, "[t] he notion that form and substance are one in law."18 In this view, the questions of what law means and how it means are two faces of the same phenomenon.

Weisberg's theme is awkwardly identified by the book's title: "Poethics" elides the phrase "poetic ethics."19 All of Weisberg's four foci have ethical value at their core. In considering these four topics in turn, I shall keep this theme central.

\section{LITERARY LAWYERS}

It is easiest to be a fox, and hardest to be a hedgehog, when examining fictional lawyers. Useful insights into the idiosyncratic character of familiar (or unfamiliar) literary figures can fail when used to support overarching inductive generalities. The Scylla and Charybdis of such efforts are obvious: Universal statements can appear to be truisms, or they can seem pithy but unconvincing.

The fiction writer's and the lawyer's predilections are at odds. The author's success depends on making her creation come alive in personal, dramatic, and surprising ways. Those facets that allow easy generalization to all $x$ (husbands, wives, lawyers, Frenchmen, persons, etc.) are least central to the work's point or significance. ${ }^{20}$ The lawyer, on the other hand, must ultimately fit individualized problems and circumstances to general rules and procedures. The need to be sensitive to relevant idiosyncracies is secondary. ${ }^{21}$

18. P. 4.

19. Weisberg explains, "Poethics ... endeavors nothing less than to fill the ethical void in which legal thought and practice now exist." P. 4.

20. A mark of poor fiction is the reduction of characters to mere stereotypes. Thus, in genre fiction (from mystery novels to television sitcoms), a successful creator camouflages stereotypes. The same can be said of so-called "high culture" from the novels of Saul Bellow to the plays of Tennessee Williams. This focus on individualism in artistic creation is part of our debt to the Renaissance and the Enlightenment. Earlier approaches to artistic subjects, for example medieval paintings or the commedia del'arte, were not presumptively individualistic.

21. Weisberg seems to question the distinction between law as generalizing and fiction as indi- 
These distinctions reveal the richness as well as the danger of the task of generalizing from the characteristics of individual literary lawyers. The lawyer who is a scholar of law and literature looks at lawyers and legal situations as refracted or created through the intervening imagination of novelists and playwrights. ${ }^{22}$ Whatever reservations one may have about deconstructive literary analysis, ${ }^{23}$ deconstruction alerts one to the levels at which shaping consciousnesses intrude and teaches that what looks simple usually is not.

A constant concern of lawyers in literature (and in life) is that practicing law constrains personality. But to constrain is not the same as to dehumanize. Whether one is an idealist or a cynic about law determines how one perceives its effects on personality. An idealist may not see law or lawyers as dehumanized; instead, she may portray the lawyer's job as realizing and safeguarding human values by using legal rules and procedures. Alternatively, a cynic may see such rules and procedures as hostile to human decency, and lawyers as the unintending or perhaps wholly enthusiastic agents of the hostile machinery of the law.

Weisberg walks two tightropes. He tries to make compelling and convincing generalizations from the lawyer-characters in his spotlight. And he tries to offer radically different readings of them from those of other scholars. A fine point, one which Weisberg never addresses directly, is whether his readings are insights into authors' original intentions. Nowhere does he raise the vexing theoretical debate over whether interpretation requires fidelity to original intent. ${ }^{24}$ Implicitly, however, he seems committed to the idea that his task as interpreter is to ferret out the authors' own meaning. For example, he rejects other critics' views of Faulkner's creation, Gavin Stevens, by asserting special insight into "Faulkner's career-long confidence in Gavin Stevens," "Faulkner's loyalty to Gavin," and "Faulkner's true voice."25 In discussing The Merchant of Venice, he claims to identify what "Shakespeare wants" and what "Shakespeare desired."26

Weisberg's discussions of literary lawyers invite several questions. How successfully and how convincingly does he make us understand familiar works in new ways? What does he discover when he generalizes from liter-

vidualizing when he writes: "In each period, law has drawn the attention of the literary artist because of its similarities to narrative art, not its differences. Law's manner of recreating and discussing reality strikes the artist as close ... to what storytellers themselves are in the business of doing." P. x. Perhaps the common law system (the accretion of law through precedent) has more in common with fiction and its individualizing methods than dos the civil law system.

22. Of course, some artists, including Franz Kafka and Louis Auchincloss, have themselves been lawyers.

23. For two book-length critiques of deconstruction, see Howard FELPERIN, BeYOND DECONSTRUCTION: THE USES AND ABUSES OF LITERARY THEORY (1985) and ROBERT SCHOLES, TeXTUAL POWER: LITERARY THEORY AND THE TEACHING OF ENGLiSh (1985).

24. See generally E.D. Hirsch, Jr., The Politics of Theories of Interpretation, in THE PoLrTics OF INTERPRETATION 321-45 (W.J.T. Mitchell ed., 1983) (arguing that all interpretation is based on the values held by the interpreter).

25. Pp. 82-83.

26. P. 100 . 
ary creations? What is the ethical or "poethical" significance of looking at literary lawyers?

\section{A. Individual Lawyers and Cases}

Any critic of plays and stories must make an early choice about presumptions; she must decide whether to assume her readers are intimately familiar with the works under discussion or to set forth evidence for her theses. The determination is obviously one of degree. Weisberg's approach varies. In his discussion of Faulkner and John Barth, he presumes that one has the relevant novels at one's fingertips. In discussing Shakespeare's Merchant of Venice and, less so, Melville's Billy Budd, he puts some of his evidence on the table and allows the reader to draw her own conclusions.

\section{Jaggers and Gavin Stevens as exemplary lawyers.}

Weisberg posits that two literary lawyers, Jaggers (who appears in Dickens' Great Expectations), and Gavin Stevens (who is a featured player in several works by Faulkner), deserve more attention and more favorable regard than most readers have accorded them. Weisberg admits that both share generously in the stereotypical failings of their profession. Thus, "Jaggers' manipulative powers, secretiveness, and distrustfulness come with the territory of his professionalism."27 And, assuming his audience is made of lawyers, Weisberg concedes that the task of examining "the personal dimension" of Gavin Stevens "is unpleasant, for it is risky: Gavin's personal traits are too close to our own. Better to see these virtues rigorously devoted to professional success, however manipulative or even unethical the tactics ...."28 Nonetheless, Weisberg insists that Jaggers' "professional perspective ... incorporates . . . some intrinsically noble concepts."29 Enthusiastically, he finds Gavin Stevens to be "the first major literary lawyer to develop positively as a human being in the direction of, and not in rebellion against, his professional strengths." 30 Contrary to most commentators, ${ }^{31}$ he concludes that "Gavin Stevens surely stands as one of contemporary literature's more sympathetic evocations." 32

Weisberg discovers virtue and humanity in Stevens and Jaggers. For Stevens, the hard-learned lesson is that "the most vital elements of human behavior are tied up in silence, not speech."33 Weisberg elaborates by saying that "Gavin gradually learns the primacy of silence over language in all vital human affairs, an easier conclusion for a lawyer to draw than one might think; ... he finally extends to his personal life his greatest virtue as a lawyer

27. P. 62.

28. P. 88.

29. P. 62.

30. P. 84.

31. See Irving Howe, William Faulkner: A Critical Study 194-99 (1952).

32. P. 92.

33. P. 89. 
...."34 Similarly, Jaggers' nobility consists in the fact that "the lawyer as a professional [is] wedded not only to his clients but also to the superb traditions of a remarkable system admittedly flawed but potentially fine."35 And yet, he concedes that for Dickens "no lawyer ... enjoys the full humanity of even the most flawed client"; ${ }^{36}$ such Dickensian lawyers are best represented by their "paradigmatic qualities," 37 including self-isolation, passivity, and mistrust of others.

That, without much elaboration, is Weisberg's defense. He alludes to, but does not explain, bits of plot in which these traits come into play. It is strikingly both a defense in content and defensive in tone. To one who is indifferent or hostile to lawyers, Weisberg's account may convey neither nobility nor virtue. Silence, discretion, and passivity are at best instrumental and professional virtues. Admiration and respect rarely, if ever, attach to these characteristics as they are carried over from professional to private life. Instead, they are widely, and properly, regarded as constraints on personality. A gap thus exists between how Weisberg describes these characters and how he demands that they should be regarded. That they are slighted or disparaged by other commentators, in turn, remains understandable. ${ }^{38}$

The analysis of Jaggers and Gavin Stevens, however, is just one of Weisberg's attempts to rehabilitate literary lawyers and lawyering. The Merchant of Venice and Billy Budd raise additional dimensions of value to which he is anxious to call attention.

\section{Portia and legalistic virtue.}

In examining the actions and attitudes of Portia in Merchant of Venice, Weisberg argues that the play consists of a series of mediations (or compromises), which Shakespeare disfavors in comparison with immediacy and directness. ${ }^{39}$ Weisberg explains that "[t]hroughout the comedy, paired characters who have a direct bond to each other are portrayed as unable to conclude their affairs without the mediation of a third character."40

\section{P. 84}

35. P. 63 .

36. P. 64 .

37. P. 61 .

38. Weisberg summarizes his account of lawyers as ethical exemplars in the following equivocal way:

First, the Anglo-American lawyer (unlike his continental counterpart) in fact stands for the closest thing to absolute values still available to us ....

....

... Lawyers see reality as a procedural game, yes; but they are right. Certain cultural periods do lack absolute guidelines, even though people's need to have beliefs and goals continues unabated. In such periods, the lawyer steps in, master of the case at hand, craftsman of proceduralism, the one who finds an end-in-itself in what is meant to be merely process.... We may complain about these modern-day shamans and manipulators, but we will pay top dollar for their sophistication.

Pp. 79-80. Am I alone in remaining puzzled by the alchemy that converts "top dollar" into proof of "absolute value" and converts "process" into "an end-in-itself"?

39. Pp. 101-03.

40. P. 95 . 
Weisberg further asserts that Shakespeare sees mediation as a structural feature of Christianity, while he identifies immediacy with earlier Jewish values. Weisberg speculates about how Shakespeare uses his heroine: Portia "first casts out the various structures of Christian mediation that have led to disaster," including "everything that Antonio, in particular, seems to her to represent."41 "Ultimately, she reinvigorates Shylock's Jewish ethics, but in a context more forgiving and less somber." 42 As evidence, Weisberg examines the often-ignored Act V, in which Portia overthrows and mocks "mediation, equity, oathbreaking" as "mere diversions" 43 and "wants . . . immediacytime alone with her husband." 44 In other words, "the structure of mediation is rejected and the keeping of promises equated with the preservation of both direct ethical commitment and precise textual responsibility."45 For Weisberg, therefore, the play is an attenuated vindication of Shylock. Portia defends the values that Shylock represented all along.

Weisberg's reading of Act V, and of the play as a whole, while imaginative and daunting, seems arbitrary and incomplete. For one thing, the structure of mediation which Weisberg finds in each act may reflect not so much Shakespeare's particular intentions and craft as it does the nature of dramatic (and comedic) conflict in general. From Sophocles to sitcoms, most dramatic scenes involve a conflict which is eventually resolved by moving it forward or off-center, frequently through mediation by a third party. Is the structure in fact more pervasive in Merchant of Venice than in other Shakespearean comedies?

Second, Weisberg fails to explain what, in his or Shakespeare's view, is wrong with mediation. Mediation opposes "precise textual responsibility"46 and is associated with equitable decisional powers used with discretion to soften harsh legal rules. Weisberg concedes that Shylock holds himself up to ridicule and condemnation for insisting on the letter of the law. ${ }^{47}$

Weisberg also never makes good on his assertion that Shylock deserves admiration rather than condemnation. This claim is unconvincing because, again, it takes an instrumental value as an evident virtue. When discussing Gavin Stevens, Weisberg endorses an ethics of passivity and silence as governing not only legal but also personal norms. Similarly, he endorses an ethic of precise textualism when analyzing Merchant of Venice, by equating Shylock's insistence on the letter of the law with direct or immediate ethical commitment. But dogged precision, like silence, is ethically neutral, usable for either good or ill.48

A related claim equates Portia's rejection of legal entanglements in Act V

41. P. 94.

42. P. 94.

43. P. 103.

44. P. 103.

45. P. 96.

46. P. 96.

47. P. 99.

48. See David Luban, LAwyers and Justice 104-47 (1988) (exploring the problem of role morality and criticizing lawyers for studied and exclusive maintenance of neutrality). 
with a rejection of mediated agreements but not direct and unmediated ones. A more plausible, if more traditional, interpretation of the play would be that Portia rejects on ethical grounds both kinds of legalism, Shylock's and Antonio's, Jewish and Christian, and endorses spontaneous relationships over rule-governed ones.

\section{Billy Budd and the abuse of law.}

Weisberg also offers a theological/ethical reading of Melville's Billy $B u d d$. Just as he argues that Merchant of Venice concerns immediacy versus mediation, he claims that Billy Budd contrasts openness with covertness. Melville's story is thus "a covert attack upon Christianity, whose antiheroic compulsion the modern writer must unwillingly accept."49 Weisberg singles out John Claggart, Billy's unintended victim, as "a hero whose initials, like those of the Gospel's hero, are 'J.C.' "so Moreover, "Claggart's position and his success in achieving it have been, like Christ's, those of a hard-working upstart. Both men attain the ultimate vindication of their 'passion' posthumously ... and ... both are transformed into heroes by authoritative accounts favoring their roles in the central events of their lives . . . ."51 Weisberg argues that Melville, upending the authoritative account, vindicates Billy over Claggart and thus elevates Old Testament values over Christian ones.

Billy Budd is, of course, a more conventional subject for vindication than Shylock, 52 and Weisberg is not the first scholar to find Christian imagery in Melville's story. ${ }^{53}$ What is controversial is his claim that in convicting and executing Billy, Captain Vere acted illegally, and not with the utmost severity of law. ${ }^{54}$ While other critics read Billy Budd as condemning the law and its rigors along with Vere, ${ }^{55}$ Weisberg provocatively asserts that Melville intends us to see the law as fair and Vere as its betrayer.

To Weisberg, Billy is a "simple, affectionate, organically just man of the sea"56 who is not at odds with law itself. Billy is not the law's victim, any more than Portia, in finally turning her back on legal mediation, is at odds with law itself (with Shylock's emphasis on enforcement of clear arrange-

49. P. 114.

50. P. 115.

51. Pp. 115-16.

52. See generally Richard Chase, Herman Melville: A Critical Study 262-66 (1971) (discussing moral symbolism in Billy Budd); F.O. MATTHIESSEN, AMERICAN RENAISSANCE 500-14 (1941) (same).

53. Both Matthiessen and Chase describe Christian imagery. CHASE, supra note 52, at 262, 264-66; MATTHIESSEN, supra note 52, at 509-12.

54. P. 106.

55. Chase describes Billy Budd as

show[ing] Melville's final admission of the tragic necessity of law in human society. . . . Captain Vere's examination and defense of law in a man-of-war world and his decision that a human life must be sacrificed to this law is impeccable, irrefutable, and fully conscious of the pathetic imagery of the situation.

CHASE, supra note 52, at 261.

56. P. 106. 
ments). Just as he did with Dickens, Faulkner, and Shakespeare, Weisberg struggles to show that Melville does not denigrate law and lawyers as custodians of value. Even though Melville's protagonist "reflects the essential harmony of outer form and inner nature that utterly negates covertness,"57 Melville does not at the same time condemn the forms and nature of law.

Weisberg's thesis is unpersuasive in two ways. At best, Melville's attitude toward law must remain uncertain. Even if Vere perverts and abuses the law, the legal forms are there to be abused and to clothe Vere's actions. Nothing in the law prescribes that Billy be saved. Moreover, Weisberg's own account of the characteristics naturally associated with lawyering-passivity, verbal manipulation, apartness, distrustfulness ${ }^{58}$ - undermines his claim that law does not necessarily support or condone covertness. None of these traits would have prevented Billy's fate, and collectively they seem to have made it possible.

\section{B. The Lessons of Literature for Lawyers}

Weisberg draws three lessons from his literary studies. The first concerns the character of lawyers. Weisberg argues that Anglo-American writers offer a "somewhat more benign" and less "gloomy" portrait of lawyers than do Continental authors, that in fact the former see lawyers as virtuous and noble. ${ }^{59}$ Second, he defends the processes of law against the charge that they necessarily or characteristically work injustice. He at least tries to persuade us that important writers such as Shakespeare or Melville did not, notwithstanding some critics, think of law as unjust. Third, Weisberg implies that true and satisfactory readings of literature will be "legalistic" in technique.

\section{Characteristics of literary lawyers.}

Weisberg sums up literary portrayals of lawyers by observing that "successful literary lawyers can be placed invariably under the sign of six remarkably consistent characteristics." 60 These are "verbal manipulation," "apartness," "distrustfulness," "professional ethical relativism," "frugality (bachelorhood)," and "passivity."61 Weisberg's discussion makes clear that these are the components of lawyers' professional and personal success.

The six characteristics define a stereotype that finds expression in literature just as it does in popular imagination and everyday discourse. But

57. P. 111.

58. Pp. 54-55.

59. "In The Failure of the Word, I examined the gloomy portrait of law in three continental novelists .... [N]ovelists in England and America were taking a somewhat more benign, if no less serious position on their legal subjects." P. 51. This general proposition seems dubious. The treatment of lawyers by continental writers such as Balzac, Chekhov, de Maupassant, A. France, and Pirandello is so varied, playful, and often sympathetic that any designation of a generally gloomy or cynical "Continental" stance toward lawyers is, at best, arbitrary. lawyers.

60. P. 54. By "success," Weisberg does not mean the success of the author in portraying

61. Pp. 54-55. 
Weisberg leaves doubts about the significance and the nature of the stereotype. Finding a few instances of the stereotype in the writings of such authors as Dickens, Barth, and Faulkner says nothing about the stereotype's universality. Even if these examples give evidence of the diffusion and popularity of the stereotype, it is in the nature of stereotypes to be diffuse and popular. Nor do these examples say much about the imaginative powers of the authors; their talent lies not in their adherence to stereotypes but rather in their ability to reconfigure them.

Weisberg's difficulty is that generalizing his point about the characteristics of literary lawyers makes it seem arbitrary and banal. The comparison with Continental writers seems arbitrary because it never amounts to more than a promissory note and because Weisberg discusses so few Anglo-American examples. Jaggers, Todd Andrews, and Gavin Stevens are his only Anglo-American examples of literary lawyers, and he does not examine a single Continental work in any detail.

Doubts about the significance of the stereotype are compounded by more serious ones about its nature. Weisberg's isolation of these six characteristics does not begin to explain his assertion that Anglo-American writers portray lawyers in a "benign" rather than "gloomy" manner. ${ }^{62}$ All six are ethically neutral or negative traits, a "gloomy" set indeed.

\section{The morality of law.}

Weisberg's discussion carries implications for the morality of law as well as the character of lawyers. We have already scrutinized the common theme in Weisberg's analyses of Merchant of Venice and Billy Budd. Both are generally understood as condemnations of law; Shylock and Vere insist on the letter of the law, demanding that it be carried out exactly as prescribed. For Weisberg, this is a bum rap; in his view, Shakespeare and Melville only fault the excesses and perversions of law, not law in general.

Does it matter whether Shakespeare or Melville was critical of law or only of its excesses? In what sense did they distinguish between the two? On the one hand, there is no evidence that Shakespeare and Melville thought law was always or generally harmful; they were not anarchists. On the other hand, Shakespeare and Melville seem to believe that law makes possible these excesses. Law makes possible the creation and enforcement of Antonio's bargain and gives Vere his power and authority. The rigid application of rules and procedures by legal authorities without mercy appalls audiences and readers. The point of Shakespeare's and Melville's criticism is not that law mandates evil results, but that it creates the monsters who perpetrate them. Shakespeare and Melville do not distinguish between law and its excesses.

The distinction between law and its excesses matters to Weisberg because he sees both works as anti-Christian, favoring direct and open administra-

62. See notes $37,38 \& 59$, supra and accompanying text. 
tion of law instead of covert and mediated application. But the openness and directness of Portia and Billy have nothing to do with rules. The primary concern of both Merchant of Venice and Billy Budd lies not in the contrast between two conceptions of law, Jewish and Christian, but between personal bonds and legal ones.

\section{Legalistic literary analysis.}

Weisberg says little about the third lesson to be drawn from literary law, the utility of the method of literary analysis he calls the legalistic technique. ${ }^{63} \mathrm{He}$ argues that reading modern fiction requires the same techniques as lawyering:

Lawyers see reality as a procedural game, yes; but they are right. Certain cultural periods do lack absolute guidelines .... In such periods, the lawyer steps in, master of the case at hand, craftsman of proceduralism, the one who finds an end-in-itself in what is meant to be merely process. We must address ourselves to such professionals when we have a problem (or even when we seek an aesthetic experience such as the reading of a novel), for only they understand how things work. ${ }^{64}$

The reach of this claim goes beyond literary lawyers. This passage, describing John Barth's creation, Todd Andrews, models general understanding of life on the understanding of lawyers. "Todd Andrews speaks of the virtue of strong relative values in an age without absolutes." 65 Having examined the implications of the creative work of nonlawyers for the understanding of law, we must turn to the ethical implications of the work of lawyers.

\section{CRAFT IN LAW}

Weisberg implies that artists have understood, while their critics have missed, the sense in which the work of lawyers is a vehicle and instrument of ethical value. The connection between law and ethics can be made by looking directly at what lawyers do.

\section{A. Cardozo on Form and Content}

Weisberg finds inspiration in Cardozo for an account of the form and content of law that challenges "standard legal methodology." 66 In doing so, Weisberg seems to have two distinguishable theses in mind. First, he argues that form and content, or sound and sense, are related intimately and inex-

63. Such defensiveness about the ethics and methods of law surfaces when Weisberg incomprehensibly calls his analytic technique "legalism." Having just discussed character traits of Claggart, Vere, Billy Budd and others in Billy Budd, he says that legalism as an analytic technique "far from narrowing the story's scope, finally encompasses the fullness of the text." P. 113. He adds that "we must seek through a legalistic rigor to find answers to the tale's most provocative questions." P. 114. He concludes, rhetorically, "Is it ironic that the legalistic method has helped to suggest the tale's most private message? No." P. 116. But "legalistic" is at best an odd synonym for "rigorous" or "imaginative."

64. P. 80 .

65. P. 81 .

66. P. 7. 
tricably. "[T]here can be no dichotomy between craft and result in law."67 $\mathrm{He}$ also asserts that any judgment about form-and-content is an ethical judgment, that is, a judgment about "the doing of justice."68 Weisberg concludes, "No opinion with a misguided outcome has ever in fact been 'well crafted." "69 Moreover, "[A]n opinion wrong in its outcome may not at the same time be excellent in its craftsmanship." 70

Neither the meaning nor the truth of Weisberg's theses is self-evident. In considering his meaning, one must first distinguish between trivial and nontrivial versions of the theses. A trivially true version of the two theses equates sound craft with ethical lucidity and correctness. A trivially false, but shallow, rendition reduces sound craft to such technical matters as logical clarity and elegant style. If craftsmanship means neither ethical insight nor logical and elegant reasoning, we must elicit another interpretation that makes Weisberg's theses nontrivial.

Reliance on Cardozo is not much help. Cardozo does offer a richly suggestive account of the relationship of form and content, but his account has none of the counterintuitive explicitness of Weisberg's. As Weisberg reminds us, Cardozo writes about " "[t]he search . . . for the just word, the happy phrase, that will give expression to the thought, but somehow the thought itself is transfigured by the phrase when found." "71 Cardozo also observes that " "opinion will need persuasive force, or the impressive virtue of sincerity and fire, or the mnemonic power of alliteration and antithesis, or the terseness and tang of the proverb, and the maxim. Neglect the help of these allies, and [the opinion] may never win its way." "72

Something makes us nod in agreement with Cardozo and mumble, "How true!" Yet we bristle at what Weisberg thinks of as his paraphrase of Cardozo's point and insist, "Show me!" Unlike Weisberg, Cardozo neither insists on the identity of form and content nor equates craft with ethics. Cardozo is not concerned with what are essentially logical relationships. Rather, he reminds us that ethical insights need to be expressed felicitously in order to compel attention and to persuade. Cardozo asserts, "We may tell judges till doomsday that they are to love logic more than justice: as in affairs of the heart generally it is easier to give the command than to cause it to be heeded." "73 Cardozo reminds us that ethically clear and resonant arguments are what good judges demand of themselves and what all of us identify with justice.

67. P. 8.

68. P. 8.

69. P. 7.

70. P. 8 .

71. P. 6 (quoting Benjamin Nathan Cardozo, The Growth of the Law, in Selected Writings of Benjamin Nathan Cardozo 185, 225 (Margaret E. Hall ed., 1947)).

72. P. 7 (quoting BenJamin Nathan Cardozo, Law and Literature, in Selected WRTtINGS OF BENJAMIN NATHAN CARDOZO, supra note 71, at 338, 342).

73. P. 6 (quoting BenJAMIN NATHAN CARDozo, Faith and a Doubting World (New York County Lawyers Address), in SELECTEd WRITINGS OF BENJAMIN NATHAN CARDozo, supra note 71, at 99, 105-06). 
But Cardozo does not seem to deny our intuitions that some abhorrent opinions may use "the mnemonic power of alliteration and antithesis," that wrongheaded opinions may take "the terseness and tang of the proverb," or that powerful and persuasive judges may at times heed mere logic and mistake it for justice. The question remains whether Weisberg believes the opposite.

To illustrate his assertions about the identity of form and content, Weisberg contrasts two modes of legal rhetoric. In the first mode, law expresses "the unity of idealism and practical duty, of nature and reason, of the spiritual and the material." 74 In the second mode, legal rhetoric is debased by textualism, logic, and literalism to become an instrument of persecution and alienation. Weisberg suggests that law in the first mode expresses "reality," while in the second, it "avoids central realities." "75 As Weisberg sees it, law and literature is the vehicle for transforming (or restoring) law in the second mode into law in the first. To illustrate his point, Weisberg dwells on two examples of the debased mode of legal rhetoric: statutory interpretation in Vichy France and the degraded use of language among contemporary American lawyers. ${ }^{76}$

In this form, Weisberg's theses are so complex that only the most impetuous and perverse critic could call them trivial. His "realities" are clearly ethical realities; in his view, law is uniquely capable of discerning and expressing such realities. When the legal system functions at its best, the style and substance of legal utterances equally and indissolubly express ideals. When it is not-when it betrays ethical reality-the failure is as much one of style as of substance.

Weisberg's arguments are breathtakingly ambitious. They include an ontological claim (there exists an ethical reality which law must either express or betray), a linguistic claim (style and substance are indissoluble), and the suggestion of a historical claim (legal rhetoric has tended to degenerate over the last few centuries from the first to the second mode). It is yet unclear what it would take to prove these claims, let alone determine whether Weisberg actually does so.

\section{B. Vichy Justice}

In his examination of legal rhetoric in Vichy France, Weisberg argues:

[U]nconstrained professional discourse more than German political pressure led to an excess of French zeal and thus a needless amount of Jewish suffering. ... [A] central risk of professionalism [is] that lawyers seek relief from considering the basic premises of their actions by recourse to eloquence, formalism, and the situational realities of the "job."77

He concludes that "it was legal practice itself and its discursive elasticity-

74. P. 213.

75. P. 128.

76. P. 215.

77. P. 145. 
and not the anti-Semitism of any one leader or group-that brought about the full extent of the horror."78 Weisberg thus tries to give an example of the moral force and responsibility of legal rhetoric. The momentum of evil lies not so much in immoral attitudes as in culpable blindness to the risks of "professionalism."

The phenomena-linguistic, legal, and psychological-that Weisberg documents so carefully and intelligently with regard to Vichy France are disturbingly familiar and common in human history. Whenever governments practice oppression and inhumanity, they are tempted to borrow legitimacy through legal formalities. The ordered and regularized application of duly enacted rules camoufiages the atrociousness of their content. The societies distinguished by such conduct have become synonyms for inhumanity: Cambodia, South Africa, Uganda, Nazi Germany, Vichy France.

Jurists in such societies face abnormal risks. ${ }^{79}$ Even when their lives are not in jeopardy, their integrity and livelihood are. They are asked to enforce rules that not only offend ethics and justice but also cause great harm. Their twin responsibilities, the formal responsibility of an administrator of rules and the ethical responsibility of an empowered human being, cannot be reconciled. Under such circumstances, these jurists often resort to evasion, with the path of literalism or formalism (one means of capitulation) serving as an available form of evasion. Even if Weisberg convincingly shows that Vichy jurists eagerly took refuge behind literalism or formalism, he does not show that they were more, or less, eager to do so than were similarly constrained judges in other systems.

How does the example of Vichy "justice" illustrate or reinforce Weisberg's main claims? The recognition of moral evasiveness does not necessarily compel us to acknowledge an ethical reality to which law is the key. Weisberg's banal (albeit distressing) recognition of moral failure under pressure does little to cause his readers to accept his controversial and ambitious ontological claim.

The content of Weisberg's claim depends on what he means by "ethical reality." For example, if he means that certain forms of conduct, such as genocide, are universally held to be ethically unacceptable whether or not they are carried out under legal forms, then Weisberg's claim about ethical reality becomes relatively uncontroversial. If, however, he means that lawyers acquire a special ability to identify the "correct" answer to otherwise generally controverted ethical questions, then the Vichy example does not significantly advance his ontological claim..$^{80}$

Similarly, Weisberg's discussion of French politics only partially advances his linguistic claim. The Vichy example does reinforce the supposi-

78. P. 146.

79. For a jurisprudential discussion of the plight of judges in such circumstances, see H.L.A. HART, The CONCEPT OF LAW 114-20 (1961). For a response to Hart's analysis, see LoN L. Fuller, The MoRality OF LAW 156-57 (1964).

80. For a recent comprehensive, sophisticated discussion and defense of the objectivity of ethics, see David O. Brink, Moral Realism and the Foundations of Ethics (1989). 
tion that lawyers under stress will pervert language, use circumlocutions to deny basic facts, and misuse words like "justice." But it does not sustain his notion that style and substance always or generally converge. For all we know of Vichy and its surrogates, judges enforcing reprehensible laws may have been able to do so without perverting language. Other judges may pervert language in the interest of arguably good causes. ${ }^{81}$

Weisberg's historical claim-that over the last two centuries legal rhetoric has moved from expressing moral reality to avoiding reality-is even less convincing than his linguistic claim. The twentieth century has no monopoly on the atrocities and accompanying rationalizations which Vichy illuminates. The trial of Christ and the slave laws of ancient Egypt show how timeless such horrors are.

Both Weisberg's analysis of Vichy France and his appropriation of Cardozo shed light on important and familiar truths of human experience. Weisberg uses Cardozo to remind us of the power of rhetoric and ethical insight and to commend law when it exhibits both. The Vichy example documents the breakdown of responsibility-the abuse of reason and abandonment of ethics-under coercion. But Weisberg's claims about ethical reality, historical change, and the identity of style and substance, are neither persuasive nor familiar; instead, his arguments are failed attempts to turn aphoristic knowledge into dogma. ${ }^{82}$

\section{Contemporary Legal Rhetoric}

Weisberg uses the example of lawyers at work to buttress all three claims, especially the historical one. He contrasts Jefferson's legal rhetoric, in which "the sentence speaks its meaning,"83 with contemporary legal prose. According to Weisberg, "today ... the lawyer may think of language as a barrier to thought rather than a carrier of it; he may denigrate rhetoric, style, and narrative to a status of strangeness or even artificiality in legal prose." ${ }^{44}$ Again, Weisberg emphasizes the identity of form and content and the importance of legal rhetoric as a vehicle of ethical self-awareness. "[Lawyers'] poor communication strategies also directly threaten their own inner peace. ... The first step to professional bliss lies, once again, on the path to strong syntax." 85

81. As a purely linguistic argument the claim that capital punishment is cruel and unusual is weak. Nonetheless, attempts to show that government-sponsored executions erode respect for life can be made into constitutional arguments by expanding the definition of what is cruel and unusual. Constitutional interpretation is rarely just a linguistic exercise; one judge's perversion of language is another's vindication of morality. Justices Brennan and Marshall argued on many occasions that the death penalty constitutes cruel and unusual punishment in all circumstances. See, e.g., Coker v. Georgia, 433 U.S. 584, 600 (1977) (Brennan, Marshall, JJ., concurring).

82. Given the centrality of ethical (or moral) realism in the work of Lon Fuller and the similarity of many of Fuller's and Weisberg's central themes, it is surprising that Weisberg barely mentions Fuller in Poethics. See note 79 supra.

83. P. 213.

84. P. 214.

85. Pp. 218-19. 
Again, one may balk at Weisberg's inflation and distortion of familiar truths. Of course, "legalese" has long been a bane of the profession; such rhetoric can obscure and distort clear thinking and can efface both the personality and ideals of the author. It is doubtful, though, that contemporary practice encourages technical jargon more than did practice in accord with the forms of action and writs in the Middle Ages. Such jargon is designed to serve rather than subvert the goals of certainty and specificity. In fact, one could argue that technical statutes like the Civil Rights Act of $1964^{86}$ actually promote and express ethical values. Finally, it is hardly fair to treat Jefferson as the exemplar of one era and cite anonymous, dysfunctional technicians as exemplars of another.

\section{Weisberg Contra Mundo}

Given his belief that legal rhetoric is the vessel of ethical reality, Weisberg is frustrated by scholars who see law and literature differently. To the extent that they emphasize form or style over substance or embrace ethical relativism, he finds their work subversive. ${ }^{87}$ Having considered the limits and ambiguities of Weisberg's own ontological, linguistic, and historical claims, we must consider how he uses them to criticize rivals.

\section{A. Weisberg's Defense of the Traditional Canon}

Weisberg discusses at great length the "misguided" strategies embodied in other approaches to law and literature. $\mathrm{He}$ is distressed in particular by postmodern scholars who criticize reliance on a traditional literary canon. ${ }^{88}$ Weisberg's subjects-including Shakespeare, Dickens, Melville, and Faulkner-are definitively traditional. Consequently, critics claim that these authors represent a partial and biased view of human experience and, therefore, of law, and that they share conceptual assumptions and purposive blindness that vitiate their claim to objectivity and truth. ${ }^{89}$

Responding to these critics, Weisberg replies that

the traditional canon hardly yields a traditional perspective, certainly not on the institution of law .... If [this] body of masterpieces . . . contains within it the seeds of a radical departure for Western culture, what more than kneejerk response would lead a progressive movement to jettison it in favor of the unknown? ${ }^{90}$

In other words, since law expresses a constant ethical reality and since traditional literature has understood and portrayed law in this way, all the neces-

86. Civil Rights Act of 1964, Pub. L. No. 88-352, 78 Stat. 241 (current version at 28 U.S.C. $\S 1447,42$ U.S.C. $\S \S 1971,1975 \mathrm{a}-1975$ d, 2000a-2000h-6 (1988)).

87. See notes $88-110$ infra.

88. Pp. 117-23.

89. See generally Jane Maslow Cohen, The Arrival of the Bee Box: Feminism, Law, and Literature, 13 HARV. WOMEN's L.J. 345 (1990) (feminist critiques of the limitations of the traditional canon); Carolyn Heilbrun \& Judith Resnik, Convengences: Law, Literature, and Feminism, 99 YALE L.J. 1913 (1990) (same).

90. P. 119. 
sary lessons about discrimination, mutual understanding, partiality, and coercion may be found in the traditional canon. In fact, while the traditional canon teaches the necessary ethical lessons, the advocates of a revised canon-one that embraces new and cacophonous voices-threaten to erode our common base of ethical understanding. Weisberg argues that "[w]e are losing a generation ... because of our own narrow postmodern agenda of value-avoidance and nonjudgmentalism. . . . Lawyers particularly need Shakespeare and Dickens more-infinitely more-than they need Derrida, Rorty, or de Man."91

Weisberg identifies the obvious absurdity of arguments that Dickens' perceptions cannot possibly be relevant to persons who are not nineteenthcentury middle-class English white men or that we must refrain from value judgments because each discrete group has its own values.92 But that is not necessarily the message of the revisionists. A more sympathetic reading is also more sensible. Revisionists do not disparage value judgments; instead, they encourage making judgments that are informed by the first-hand experiences of those whom society would help, judge, or punish. For instance, the depiction of women-their needs, rights, and understanding-in Dickens is often caricature and in Melville it is negligible. It is better, perhaps, to turn to George Eliot and Jane Austen.

Weisberg not only misconstrues critics of the traditional canon but also argues that their critiques are irrelevant. "[S] uppose that the [law and literature] movement had programatically avoided feminist and postmodernist influences. ... [I]t cannot fairly be resented of one progressive line of thinking that it pays scant attention to other contemporaneous innovators."93 Weisberg suggests this critique is irrelevant, just as it would be "to suggest that Freud, in avoiding Marx, was unprogressive." 94

This claim is doubly unpersuasive. First, Weisberg assumes that the feminist and postmodernist movements are merely variant approaches to law and literature. In other words, he ignores the fact that these movements essentially embody arguments about the ethical bias and untrustworthiness of the traditional approach. The comparison with Freud and Marx is similarly unpersuasive. They are hardly thinkers who are mutually irrelevant; a Marxist necessarily sees Freud as disregarding the psychological impact of economy and class, and a Freudian must at her peril address this criticism.

\section{B. Weisberg's Critique of His Peers}

While Weisberg's defense of the traditional canon is sketchy, his critique of such law and literature scholars as Stanley Fish, James Boyd White, and Richard Posner is detailed. Weisberg is troubled by what he regards as insidious and subversive ethical relativism. " '[P]ost-modernist' hermeneutics

91. Pp. 120-21.

92. Pp. 117-23.

93. P. 119.

94. P. 119. 
... directly risks producing modes of practice that replicate Vichy's textavoidance, relativism, and ethical debasement. . . . Post-Holocaust (a term I prefer to postmodern) theories that appear to liberate legal rhetoric from ethical norms are at best untimely and at worst perverse."95

Fish is raked over the coals for holding "the view that professional norms cannot exist apart from the practices of the community allegedly bound by those norms. . . . [I]deals, norms, beliefs, can never constrain professional behavior." 96 Fish, according to Weisberg, argues that "whatever is, is right" because the immediate context of an utterance or text is always supplied by the interpretive community which defines its meaning. ${ }^{97}$

This is not the place for the kind of critical exegesis of Fish that would be required to evaluate a criticism such as Weisberg's. ${ }^{98}$ But Weisberg's rhetoric spawns two doubts. First, as we saw above, his assumptions about ethical reality are simply assumptions. It is hard to understand what standards, other than those of the immediate interpretive community, are appropriate to judge a professional performance. More importantly, Fish and Weisberg are not necessarily incompatible. For example, one may argue that the effects of coercion and evasion found in Vichy rhetoric are morally criticizable by appeal to standards of that very interpretive community. It is hard to believe otherwise, that the notions of hypocrisy, capitulation, and bad faith were not part of the intellectual arsenal of Vichy France itself. To believe otherwise would be to dehumanize the malefactors in such a way that ethical judgment should not apply. Therefore, Weisberg's own conclusions can be derived from Fish's framework.

Weisberg's elaborate discussion of James Boyd White concludes with a similar critique. Weisberg summarizes White's most recent version of his thesis as saying that law is neither a matter of rules nor politics but rather a form of rhetoric. Language is inherently ambiguous and imprecise, but a judge can use language to "reconstitute community" if he is mindful of its pitfalls and limitations. ${ }^{99}$

According to Weisberg, White, like Fish, offers no objective ethical standard that "helps the legal actor to understand the rightness of his or her 'translation' [of legal rhetoric] . . . . Denying the claim that law is merely political rhetoric, White nonetheless fails to inform his reader of any standard by which the rhetoric of judgment should otherwise be evaluated."100 Weisberg sees White's lapses, unlike Fish's, as the unintended fruits of com-

95. P. 145.

96. P. 173.

97. Pp. 173-74.

98. The critical literature on Fish's work is extensive. He has had sustained debates with both Ronald Dworkin and Owen Fiss. See, e.g., Ronald Dworkin, My Reply to Stanley Fish (and Walter Benn Michaels): Please Don't Talk About Objectivity Any More, in The Politics of INTERPRETATION, supra note 24, at 287; Owen M. Fiss, Comments: Conventionalism, 58 S. CAL. L. REv. 177 (1985); David Luban, Fish v. Fish, or, Some Realism About Idealism, 7 CARDozo L. REv. 693 (1986).

99. Pp. 224-25.

100. Pp. 226-27. 
placency: " $[\mathrm{H}] \mathrm{e}$ has created an apologetically descriptive, not a normative, manual for what goes on anyway. And this is fine if, as in Stanley Fish, it is intended; I do not think White intended such complacency."101

Curiously, this criticism undercuts Weisberg's own commitment to the identity of style and substance. First, he chastises White for thinking naively that language and rhetoric are the vehicles of truth and ethics: "[A] purely rhetorical [vision of law] . . . is hardly a vision of law that can be called 'ethical." "102 He offers as an example the way some Western legal cultures have seemed to function well while being both "rhetorically satisfying"103 and racist or otherwise unethical. Yet, on the very next page, Weisberg reminds us of one of his fundamental theses, that "no [morally] bad judicial opinion can be 'well written." "104 This thesis is true, it seems, only when it is not stated by a rival. Weisberg then, ironically, turns the charge of inconsistency on White, saying that a passage in White's recent work "is fraught with so much inconsistency that we can only credit it as worth our time if we view it as just so much sound."105

Weisberg also criticizes Richard Posner's law and literature theories, charging Posner with ethical relativism. Weisberg argues that Posner explicitly equates might with right, "accept[ing] authoritative declarations both at face value and as innately good."106 Because Posner is unconcerned with the ethical criticism of law, he also cannot conceive of using literature as a monitor of law's fidelity to ethical reality. For Weisberg, on the other hand, "law gains prominence in literature in several specific times and places," contexts in which "judges and prosecutors join [the] group of potential terrorizers." 107 Literature, in being critical of law, calls it to its mission, "the long and difficult process of describing things articulately - of putting a narrative structure around an otherwise inchoate reality." 108 In other words, literature provides an ethical structure for law. Consequently, Posner's call for a flexible jurisprudence, one that replaces formal rules with an equitable approach to value seems dangerous to Weisberg: "In periods such as our own, when there is no binding culture or prevailing sense of rightness, flexibility is risky." 109

However, Weisberg's criticism of flexibility can be turned against him. Weisberg's claims are problematic even if one concedes his negative arguments, that Posner has a narrow and Procrustean conception of the ways in which law fails ethically and that ethical criteria cannot be reduced to eco-

101. P. 243. Of course, in another sense, Weisberg does not regard Fish's theses as "fine" at all. See text accompanying notes 96-98 supra.

102. P. 249.

103. P. 250 .

104. P. 251.

105. P. 247 (criticizing JAMES Boyd White, Justice as Translation: AN ESSAY in CuLTURAL AND LeGAI CRITICISM 178 (1990) (discussion of the rule created in Miranda v. Arizona, 384 U.S. 436 (1966)).

106. 'P. 191.

107. P. 202

108. P. 202.

109. P. 210 . 
nomic and political ones. ${ }^{110}$ Adherence to particular economic and political norms does not exempt legal decisions from ethical criticism. Nevertheless, such ethical criticism is not univocal. Weisberg's view is inflexible because he fails to acknowledge that literature necessarily speaks with many voices. Those who create literature, no more and no less than those who write legal texts as judges or legislators, have conflicting ethical insights and occasionally none at all. One hopes that works of literature and legal texts will give ethical guidance, but a hope is not a mission. Some works of literature may have their value in replicating chaos rather than in giving order. Others may have value in exemplifying, rather than condemning, dangerous values. Only if we know that one ethical reality exists and also know its substance can we, as Weisberg commends, eschew "flexibility."

\section{STYLE}

Both courtesy and good sense dictate that the style of a jurisprudential monograph is a tertiary concern at best. Noteworthy and provocative legal theorists are not necessarily masters of style. Their ideas are what matter, not the mode of presentation. Moreover, a critique of style threatens to remind readers of the adage of the pot and the kettle.

It is impossible to show such discretion with Poethics. First, Weisberg himself gives center stage to the thesis that style and substance are indivisible; a failure of one is a failure of the other. ${ }^{111}$ Second, Weisberg argues that the lesson to be drawn from studying literature is as much a lesson about style as one about substance. ${ }^{112}$ Directness, immediacy, and clarity of style lead to substantive ethical insight.

Weisberg thus holds himself to a Draconian test. We can dismiss style as relatively unimportant only by dismissing his thesis in the bargain. Provisionally, at least, we must assume style really matters. Disturbingly, Weisberg's style does not deserve a passing mark.

\section{A. Lack of Clarity}

Throughout this review, I have left certain points sketchy because of vagueness in Weisberg's argument. The most damaging aspect of his style is its indirection. For example, he writes that "literature provides the best jurisprudential chance for fathoming the complex effects of theoretical equality upon hierarchically nonequal citizens of a bourgeois democracy."113 The following statement which attempts to accord White's argument some success is even more opaque:

And if Heracles' Bow has not succeeded in the formidable task of justifying

110. See Jules L. Coleman, Efficiency, Utility, and Wealth Maximization, 8 HOFSTRA L. REV. 509, 520-40 (1980); Ronald Dworkin, Why Efficiency?: A Response to Professors Calabresi and Posner, 8 HOFSTRA L. REV. 563, 573-90 (1980).

111. See text accompanying notes 66-70 supra.

112. See text accompanying notes 75-76 supra.

113. P. 212. 
rhetoric (either generally or as its author would like it practiced), the book surely extends admirably his once equally ambitious project (now, in part thanks to him, fully acceptable) of emphasizing the imaginative, narrative, and fictive elements that pervade the lawyer's life. ${ }^{114}$

\section{B. Structure}

The book has a uniquely odd structure. For the most part, it brings together essays and lectures written by Professor Weisberg for various publications and audiences. Six numbered chapters incorporate these essays and lectures, largely unmodified from their original appearance, as subparts. These resurrected pieces are also numbered sequentially. For example, chapter two includes essays numbered 5 through 9, chapter five includes essays 13 and 14 , and so on. Moreover, the six chapters fall within the three numbered main parts of the book. Thus, three different and independent numbering systems coexist. ${ }^{115}$

\section{Lawyerisms}

Weisberg accuses lawyers, quite justifiably, of excessive use of qualifiers. They pepper their prose with so many qualifications, so many conceptual safe havens, that they undercut meaning. Unfortunately, Weisberg exemplifies this style throughout Poethics. Consider this statement: "The nineteenth century, perhaps particularly, took an almost definitional stance toward lawyers, so that even disinterested descriptions often managed to be implicitly derogatory."116 On the next page, Weisberg is similarly tentative: "[T]he image of the lawyer in twentieth-century fiction somewhat modifies the pejorative view of the nineteenth-century novelist, while perhaps increasing ... the sense of bewilderment before the law . ..."117 Indeed, perhaps it is almost impossible for Weisberg to perpetrate an argument without "indeed," "perhaps" and "almost."

\section{Tone}

We saw that Cardozo is more circumspect than Weisberg in describing the relationship of style and substance. ${ }^{118}$ Though he does not identify style with substance, Cardozo emphasizes the ways in which thought can be transfigured by apt phrases. For Cardozo, the relationship is complex; while good style is not the inevitable vehicle of good thinking, infelicities of style can distort ideas.

In Poethics, Weisberg's taste for impersonality and for propounding philosophical and conceptual theses makes his writing appear grandiose and hy-

114. P. 244.

115. Among other effects, the peculiar numbering system makes Weisberg's endnotes extremely difficult to retrieve and correlate.

116. P. 52.

117. P. 53.

118. See text accompanying notes $71-73$ supra. 
perbolic. At the outset, he declares breathtakingly that "[p]oethics . . . endeavors nothing less than to fill the ethical void in which legal thought and practice now exist." $119 \mathrm{He}$ announces that "the aim of [one] essay [is] to elaborate on the identifiable traits that make of Jaggers a paradigm for all subsequent Anglo-American fictional lawyers."120 Having discussed Merchant of Venice, he concludes that "Shakespeare says more in one play than all the rest of us English-speakers combined."121

While he exalts Shakespeare, Weisberg disdains rival scholars. Introducing his critique of Posner, he writes that "[n]ever, it seems, have so many of the world's most distinguished imaginative works left so apparently bright a reader so unmoved; rarely has mere assertion so prevailed over goodly demonstration in so well-researched a scholarly endeavor."122 Weisberg adds that Posner "is out of his element" when he discusses romanticism: "Romanticism is a tough nut to crack, and it is a concept he has not yet mastered." 123 We have already seen that he treats White in a similarly dismissive way, suggesting that we view his work as "just so much sound" 124 and referring to White's "wholesale dismissal of all other academic discourse."125 Perhaps we are again in the domain of aphoristic pots and kettles.

\section{CONCLUSION}

Poethics forces one to think hard about important questions. Weisberg's interests and sophistication are as broad as his ambition. He shares with Fish, White, and Posner the goal of giving a focus to studies in law and literature. His own conception of that focus leads him to make philosophical, literary, psychological, and historical claims-claims that concern the existence of ethical reality, the unity of style and substance, the effects of legal rhetoric on lawyers and the practice of law, and the alienation over time of lawyers and scholars from moral reality.

Even though Weisberg believes otherwise, it is no failing of law and literature that it cannot supplant other jurisprudential disciplines and vindicate so far-reaching a program. Weisberg could pursue a more modest goal by making two concessions. First, insofar as the field remains benignly inchoate, the disparate ways of examining law and literature discussed earlier remain available options. ${ }^{126}$ Second, Weisberg could conceive the specific aspects of his program more clearly, modestly, and flexibly-more in the spirit of Cardozo. Inquiry into shared ethical foundations and ethical diver-

119. P. 4.

120. P. 59.

121. P. $121-22$.

122. Pp. $189-90$.

123. P. 205. For Weisberg, the meaning of Romanticism is clear-it is associated with authoritarianism. With great decisiveness, he makes the dubious claim that "the romantic state of mind is the most likely to endure the most depraved of tyrannies without rebellion." P. 204.

124. P. 247.

125. P. 245.

126. See text accompanying notes 3-11 supra. 
sity and into the relation of style and substance seems to yield complex accounts of experience rather than iconoclastic pronouncements. The beginning of wisdom is seeing that experience includes both ethical agreement and ethical controversy. While style may reinforce substance, it may also camouflage lack of substance, just as substance may be veiled by lack of style. Notwithstanding Weisberg's arguments, multiple approaches to abstract questions and to particular texts remain valid and invigorate the discipline.

Finally, modesty counsels that neither lawyers nor creators of literature have a special franchise on style or on ethical substance. Each can learn from others and indulge in justifiable criticisms. Weisberg deserves congratulations for the scope of his vision, for the vigor of his arguments, and for leading us not to acquiesce in his conclusions but to consider such important questions for ourselves. 
